\title{
ANALISIS FAKTOR YANG MEMPENGARUHI KEBIJAKAN DIVIDEN PADA PERUSAHAAN MANUFAKTUR YANG TERDAFTAR DI BURSA EFEK INDONESIA
}

\author{
FlourienNurul $\mathrm{CH}^{1}$, Zahratunnissa Ulya ${ }^{2}$ \\ Sekolah Tinggi Ilmu Ekonomi Indonesia \\ J1. Kayu Jati Raya No. 11A, Jakarta 13220, Indonesia \\ flonurul@gmail.com
}

\begin{abstract}
This study aims to determine the effect of liquidity position, leverage, profitability, and firm size against dividend policy. Dependent variable in this research is dividend policy measured by dividend payout ratio. Independent variables used are the position of liquidity, leverage, profitability, and company size. This research is an associative research with a causal approach. The population of this research is a manufacturing company listed in Indonesia Stock Exchange (BEI) in 2012 until 2014. Samples determined by purposive sampling method, with the number of samples of 28 manufacturing companies so that the total observation in this study as much as 84 observations. The data used in this research is secondary data. Data collection techniques using documentation method through IDX official website: www.idx.co.id.Metode data analysis used is multiple linear regression analysis with the help of software SPSS for Windows 22.Result research proves that the liquidity position does not affect the dividend policy on the company manufacturing listed on the Indonesia Stock Exchange (BEI) for the period 2012-2014. Profitability and firm size have a positive effect on dividend policy on manufacturing companies listed in Indonesia Stock Exchange (IDX) period 20122014, and leverage negatively affect dividend policy on manufacturing companies listed in Indonesia Stock Exchange (IDX) period 20122014.
\end{abstract}

Keywords: Dividend Policy, Liquidity Position, Leverage, Profitability, and Company Size.

\section{PENDAHULUAN}

Menurut Irham Fahmi (2012), Pasar Modal adalah tempat dimana berbagai pihak khususnya perusahaan menjual saham (stock) dan obligasi (bond) dengan tujuan dari hasil penjualan tersebut nantinya akan dipergunakan sebagai tambahan dana atau untuk memperkuat modal perusahaan. Sementara investor dalam menginvestasikan dananya ke suatu perusahaan dalam bentuk saham akan dihadapkan pada return saham dalam bentuk dividen dan capital gain. Capital gain merupakan keuntungan modal yang diperoleh dari selisih antara harga beli dan harga jual saham, sedangkan dividen adalah porsi laba bersih yang dibagikan oleh perusahaan kepada para pemegang saham.

Pembayaran dividen menurut Megginson (1997) dalam Nursandiri (2015) adalah sangat mahal baik bagi perusahaan yang melakukan pembayaran karena pembayaran dividen akan mengurangi jumlah dana yang dipergunakan untuk 
investasi, maupun bagi para pemegang saham yang menerima pembayaran dividen karena mereka harus membayar pajak atas dividen. Hal ini menunjukkan bahwa hanya perusahaan yang benar-benar sehat dan kuat saja yang mampu membayar dividen, sedangkan badan usaha dengan kemampuan terbatas akan sangat kesulitan dalam membayar dividen. Oleh karena itu penting bagi manajer keuangan untuk mengetahui faktor-faktor yang mempengaruhi kebijakan dividen yang nantinya akan menunjukkan kualitas perusahaan sehingga investor tertarik untuk membeli saham perusahaan.

Kebijakan dividen adalah suatu keputusan perusahaan untuk menentukan berapa besarnya laba bersih yang akan dialokasikan sebagai dividen dan berapa laba yang akan diinvestasikan kembali ke perusahaan dalam bentuk laba ditahan. Kebijakan dividen sangat penting karena mempengaruhi kesempatan investasi perusahaan, harga saham, struktur finansial, arus pendanaan dan posisi likuiditas (Puspita, 2009).

Kebijakan dividen suatu perusahaan akan melibatkan dua pihak yang berkepentingan dan saling bertentangan (agency conflict), yaitu kepentingan para manager (agent) yang bertujuan untuk memakmurkan dan memaksimalkan nilai perusahaan. Sementara kepentingan para pemegang saham (principal)yang menginginkan proyek dengan expected return yang tinggi. Sayangnya dalam dunia nyata, investasi yang memberikan return yang tinggi, risikonya juga tinggi (Sartono, 2001 dalam puspitasari 2014). Tingginya risiko akan menyebabkan kreditur ikut menanggung risiko.

Konflik keagenan yang terjadi antara manajer dan pemegang saham dapat diminimalisir dengan suatu mekanisme pengawasan. Namun, munculnya mekanisme pengawasan tersebut akan menimbulkan biaya bagi para pemegang saham. Biaya yang dikeluarkan untuk mengatasi masalah keagenan disebut dengan biaya keagenan (agency cost). Easterbrook (1984) dalam Nurkholis (2015) menyatakan bahwa dividen dapat berperan sebagai mekanisme untuk mengatasi masalah keagenan. Peningkatan pembayaran dividen akan mendorong perusahaan untuk mencari sumber pendanaan eksternal di pasar modal. Dengan masuknya perusahaan ke pasar modal, maka perusahaan akan mendapat pengawasan dari para investor luar sehingga dapat menekan para manajer untuk bertindak demi kepentingan para pemegang saham. Dengan demikian, dividen dapat menjadi alat monitoring sekaligus bonding untuk mengontrol perilaku para manajer.

Penelitian ini termotivasi dari penelitian yang dilakukan oleh Novia Ayu Puspitasari (2014), dengan judul "Faktor-faktor yang Berpengaruh terhadap Kebijakan Dividen pada perusahaan manufaktur yang terdaftar di BEI selama periode 20092011". Penelitian tersebut menggunakan arus kas bebas, collateral asset, leverage (Debt to Equity Ratio), dan profitabilitas (ROA) sebagai variabel independen. Sedangkan Kebijakan Dividen sebagai variabel dependen. Hasil penelitian menunjukan bahwa variabel debt to equity ratio dan profitabilitas $(R O A)$ secara parsial berpengaruh signifikan terhadap kebijakan dividen pada level signifikansi kurang dari 1 persen, sementara variabel arus kas bebas dan collateral assets secara parsial tidak signifikan terhadap kebijakan dividen, sedangkan secara bersama-sama arus kas bebas, collateral assets, debt to equity ratio dan profitabilitas terbukti berpengaruh signifikan terhadap kebijakan dividen pada level kurang dari 1 persen. Berbeda dengan penelitian yang dilakukan Novia Ayu Puspitasari, peneliti menggunakan posisi likuiditas (current ratio), leverage (debt to assets ratio), profitabilitas (earning per share), dan ukuran perusahaan sebagai variabel independen, sementara kebijakan dividen sebagai variabel dependen.

Likuiditas merupakan kemampuan perusahaan untuk melunasi kewajiban jangka pendeknya. Dalam penelitian Palino (2012) yang menyatakan bahwa likuiditas 
(current ratio) berpengaruh dan signifikan terhadap kebijakan dividen. Karena semakin besar posisi kas dan likuiditas perusahaan secara keseluruhan akan semakin besar pula kemampuan perusahaan untuk membayar dividen. Berbeda dengan Taufani (2014) dan Pasadena (2013), dalam penelitiannya menyatakan bahwa tidak terdapat pengaruh yang signifikan dari current ratioterhadap dividend payout ratio. Karena posisi likuiditas yang tinggi dapat menunjukkan bahwa perusahaan tidak mampu menggunakan asset lancarnya secara optimal.

Leverage merupakan tingkat penggunaan utang sebagai sumber pembiayaan perusahaan. Dalam penelitian ini, debt to assets ratio digunakan dalam pengukuran leverage. Puspita (2009) menyatakan bahwa leverage (debt to asset ratio) tidak berpengaruh signifikan terhadap devidend payout ratio. Berbeda dengan penelitian yang dilakukan oleh Nuringsih (2005) dalam Santoso (2012), bahwa ada pengaruh negatif Leverage (debt to assets ratio) terhadap kebijakan dividen.

Profitability Ratio merupakan rasio untuk mengukur kemampuan perusahaan memperoleh laba dalam hubungannya dengan penjualan, total aktiva maupun modal sendiri (Nursandari, 2015). Rasio ini sangat diperhatikan oleh calon investor maupun pemegang saham karena berkaitan dengan harga saham serta dividen yang akan diterima. Profitabilitas diduga berpengaruh terhadap Kebijakan Dividen. Menurut Suharli (2006) profitabilitas berpengaruh positif terhadap kebijakan dividen. Hal ini sesuai dengan Signalling Theory, pihak manajemen akan membayarkan dividen untuk memberi sinyal mengenai keberhasilan perusahaan membukukan profit. Pemaparan teori sinyal tersebut didukung bukti empiris Lintner (1956) dalam Santoso (2012) yang menyimpulkan bahwa kemampuan perusahaan untuk membayar dividen merupakan fungsi dari keuntungan. Lebih lanjut Lintner (1956) dalam santoso (2012) mengemukakan bahwa perusahaan hanya akan meningkatkan dividen apabila earnings meningkat..

Penelitian tersebut sejalan dengan penelitian yang dilakukan Nursandari (2015), dan Marlina dan Danica (2009) dalam Puspitasari (2014) memberikan hasil bahwa profitabilitas berpengaruh positif signifikan terhadap kebijakan dividen. Dengan kata lain, semakin besar keuntungan yang diperoleh,semakin besar kemampuan perusahaan dalam membayar dividen. Berbeda dengan penelitian Dewi (2008) yang menyatakan profitabilitas berpengaruh negative signifikan terhadap kebijakan dividen karena apabila perusahaan memiliki laba yang tinggi, maka perusahaan akan menggunakan laba tersebut untuk ekspansi sehingga akan mengurangi pembagian dividen. Dalam penelitian ini, peneliti menggunakan earnings per share dalam mengukur profitabilitas.

Ukuran perusahaan merupakan salah satu alat untuk mengukur besar kecilnya perusahaan. Perusahaan besar mungkin lebih memiliki pemikiran yang luas, skill karyawan yang tinggi, sumber informasi yang banyak dibandingkan dengan perusahaan kecil. Menurut Dewi (2008) dan Santoso (2012), menyatakan bahwa ukuran perusahaan berpengaruh positif dan signifikan terhadap Kebijakan Dividen, hal ini karena semakin besar ukuran perusahaan maka semakin tinggi kebijakan dividen. Sementara Nuringsih (2005) dalam Santoso (2012) dalam penelitiannya mengungkapkan bahwa ukuran perusahaan tidak memiliki pengaruh yang signifikan terhadap Kebijakan Dividen.

Dengan melihat uraian diatas, masih terdapat hasil penelitian yang tidak konsisten, sehingga penulis tertarik untuk meneliti lebih lanjut mengenai "Analisis Faktor Yang Mempengaruhi Kebijakan Dividen pada Perusahaan Manufaktur yang terdaftar di Bursa Efek Indonesia." 


\section{KAJIAN LITERATUR}

Kebijakan dividen adalah keputusan mengenai apakah laba yang diperoleh perusahaan akan dibagikan kepada pemegang saham sebagai dividen atau akan ditahan dalam bentuk laba ditahan guna pembiayaan investasi pada masa yang akan datang. Dalam kebijakan dividen, terdapat trade off dan merupakan pilihan yang tidak mudah antara membagikan laba sebagai dividen atau menahan untuk diinvestasikan kembali. Apabila perusahaan memilih membagikan laba sebagai dividen maka tingkat pertumbuhan akan berkurang dan akan berdampak negative terhadap harga saham. Di sisi lain, apabila perusahaan tidak membagikan dividen maka pasar akan melihat sebagai sinyal negatif atas prospek perusahaan.

\section{Pengaruh Posisi Likuiditas terhadap Kebijakan Dividen}

Fred Weston dalam Kasmir (2015:129) menyebutkan bahwa rasio likuiditas merupakan rasio yang menggambarkan kemampuan perusahaan dalam memenuhi kewajiban (utang) jangka pendek. Posisi likuiditas diduga berpengaruh positif terhadap kebijakan dividen. Karena semakin kuat posisi likuiditas maka semakin besar kemampuan perusahaan untuk membayar utang jangka pendeknya. Dengan semakin kuatnya posisi likuiditas juga dapat meningkatkan kepercayaan para pemegang saham bahwa perusahaan dapat membayar dividen sesuai yang diharapkan pemegang saham.Hal ini sejalan dengan penelitian yang dilakukan oleh Palino (2012) yang menyatakan bahwa likuiditas berpengaruh dan signifikan terhadap kebijakan dividen.

H1 : Posisi likuiditas berpengaruh positif terhadap Kebijakan Dividen

\section{Pengaruh Leverage terhadap Kebijakan Dividen}

Rasio solvabilitas atau leverage ratio merupakan rasio yang digunakan untuk mengukur sejauh mana aktiva perusahaan dibiayai oleh utang. Artinya berapa besar beban utang yang ditanggung perusahaan dibandingakn dengan assetnya. Dalam arti luas dikatakan bahwa leverage digunakan untuk mengukur kemampuan perusahaan untuk membayar seluruh kewajibannya, baik jangka pendek maupun jangka panjang. Dalam penelitian ini, digunakan Debt to assets ratio dalam mengukur besar kecilnya leverage perusahaan.

Puspita (2009), menyatakan bahwa semakin besar rasio debt to asset ratio menunjukkan semakin besarnya tingkat ketergantungan perusahaan terhadap pihak eksternal (kreditur) dan semakin besar pula beban biaya hutang (biaya bunga) yang harus dibayar oleh perusahaan. Dengan semakin meningkatnya rasio debt to asset ratio, maka hal tersebut berdampak terhadap profitabilitas yang diperoleh perusahaan, karena sebagian digunakan untuk membayar bunga pinjaman. Dengan biaya bunga yang semakin besar, maka profitabilitas (earnings after tax) semakin berkurang (karena sebagian besar digunakan untuk membayar bunga), maka hak para pemegang saham (dividen ) juga semakin berkurang. Chang dan Rhee (1990) dalam puspita (2009) juga menunjukkan bahwa tingkat hutang yang lebih rendah mengikuti pembayaran dividen perusahaan yang lebih tinggi, dengan demikian debt ratio mempunyai hubungan yang negatif dengan dividen.

$\mathrm{H} 2$ : Leverage berpengaruh negatif terhadap Kebijakan Dividen 


\section{Pengaruh Profitabilitas terhadap Kebijakan Dividen}

Rasio profitabilitas merupakan rasio untuk menilai kemampuan perusahaan dalam mencari keuntungan. Rasio profitabilitas yang digunakan dalam penelitian ini adalah earnings per share atau laba per saham biasa. Darminto (2007), Earning per Share (EPS) menunjukkan besarnya earning yang diperoleh dari setiap lembar saham. EPS merupakan rasio dari earning after tax dengan jumlah saham yang beredar. EPS menggambarkan jumlah keuntungan yang seharusnya diterima oleh para pemegang saham sesuai dengan jumlah saham yang dimiliki. Earning per share tidak selalu dibagikan, jika perusahaan memerlukannya maka tidak dibagikan kepada para pemegang saham.

Profitabilitas diduga berpengaruh positif terhadap kebijakan dividen. karena semakin besar profitabilitas yang dimiliki perusahaan, maka semakin besar kemampuan perusahaan dalam membayar dividen. Hal ini sesuai dengan penelitian yang dilakukan oleh Nursandari (2014) dan Puspitasari (2014), bahwa profitabilitas berpengaruh positif dan signifikan terhadap kebijakan dividen.

H3 : Profitabilitas berpengaruh positif terhadap Kebijakan Dividen

\section{Pengaruh Ukuran Perusahaan terhadap Kebijakan Dividen}

Ukuran perusahaan di duga berpengaruh positif terhadap kebijakan dividen. Karena semakin besar sebuah perusahaan, maka akses ke pasar modal pun akan lebih mudah. Sehingga perusahaan memiliki kesempatan yang lebih besar dalam memperoleh dana. Dengan demikian, perusahaan besar mampu membayar dividen yang lebih besar dibanding perusahaan kecil. Hal ini sejalan dengan penelitian yang dilakukan Dewi (2008) dan Santoso (2012), yang menyatakan bahwa ukuran perusahaan berpengaruh positif dan signifikan terhadap kebijakan dividen.

H4 : Ukuran Perusahaan berpengaruh positif terhadap Kebijakan Dividen

\section{METODE PENELITIAN}

\section{Model Pengujian Hipotesis}

Dalam uji hipotesis, peneliti menggunakan model regresi linier berganda dengan tujuan untuk menguji apakah terdapat pengaruh dari dua atau lebih variabel independen (bebas) terhadap variabel dependen (terikat). Untuk menguji hipotesis, maka rumus persamaan regresi yang digunakan adalah sebagai berikut :

$\mathrm{DPR}=\alpha+\beta_{1} \mathrm{CR}+\beta_{2} \mathrm{DAR}+\beta_{3} \mathrm{EPS}+\beta_{4} \mathrm{SIZE}+\varepsilon$

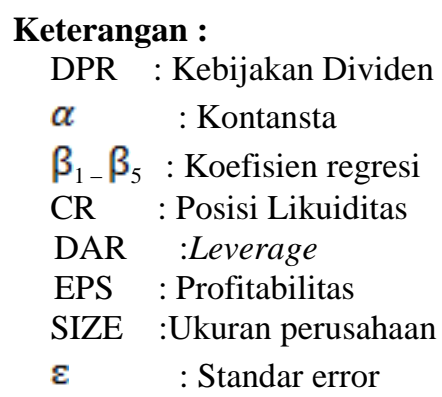




\section{Definisi dan Operasionalisasi Variabel}

Variabel dependen yang digunakan adalah kebijakan dividen yang diukur dengan dividend payout ratio. Variabel independen yang digunakan adalah posisi likuiditas yang diukur dengan current asset, leverage yang diukur dengan debt to asset ratio, profitabilitas yang diukur dengan earnings per share, dan ukuran perusahaan yang diukur dengan Ln total asset.

\section{Data dan Sampel Penelitian}

Dalam penelitian ini, data yang digunakan adalah data sekunder, yaitu sumber data penelitian yang diperoleh peneliti secara tidak langsung melalui media perantara (diperoleh dan dicatat oleh pihak lain. Data sekunder umumnya berupa bukti, catatan atau laporan historis yang telah di dokumentasikan. Data sekunder yang digunakan adalah laporan keuangan dan annual report semua perusahaan manufaktur yang terdaftar di Bursa Efek Indonesia (BEI) selama periode 2012 sampai dengan 2014.

Dalam penelitian ini, ada 131 perusahaan manufaktur yang terdaftar di Bursa Efek Indonesia periode 2012 sampai dengan 2014 sebagai populasi. Pengambilan sampel menggunakan teknik purposive sampling, yaitu pengambilan sampel berdasarkan kriteria tertentu untuk mendapatkan sampel yang representatif. Kriteria dalam pengambilan sampel penelitian ini sebagai berikut :

1. Perusahaan manufaktur yang terdaftar di Bursa Efek Indonesia (BEI) selama periode 2012 sampai dengan 2014.

2. Perusahaan yang mempublikasikan annual report dan laporan keuangan auditan di Bursa Efek Indonesia dengan tahun buku yang berakhir 31 Desember selama periode 2012-2015.

3. Perusahaan manufaktur yang menggunakan mata uang rupiah $(\mathrm{Rp})$ dalam penyajian laporan keuangan.

4. Perusahaan manufaktur yang tidak mengalami kerugian selama periode 2012 sampai dengan 2014.

5. Perusahaan manufaktur yang selalu membayar dividen selama periode 2012 sampai dengan 2014.

6. Perusahaan manufaktur yang tidak melakukan pemecahan saham

\section{Metode Analisis Data}

Metode statistik yang digunakan untuk menguji hipotesis dalam penelitian ini adalah regresi linier berganda dengan menggunakan bantuan softwareSPSS for Windows 22, maka analisis data yang digunakan dalam penelitian ini sebagai berikut :

1) Uji Statitsik Deskriptif

2) Uji Asumsi Klasik
a) Uji Normalitas
b) Uji Autokorelasi
c) Uji Multikolonieritas
d) Uji Heterokedastisitas

3) Uji Hipotesis
a) Koefisiensi Determinasi $\left(\mathrm{R}^{2}\right)$
b) Uji Signifikansi Simultan (Uji Statistik F)
c) Uji Signifikan Parameter Individual (Uji Statistik t)

\section{HASIL PENELITIAN DAN PEMBAHASAN}

\section{Hasil Uji Statistik Deskriptif}


Hasil Uji Statitistik Deskriptif dapat dilihat pada tabel 1

\begin{tabular}{|c|c|c|c|c|c|}
\hline & & Hasil Uji Stat & ik Deskriptif & & \\
\hline Descriptiv & e Statistics & & & & \\
\hline & $\mathrm{N}$ & Minimum & Maximum & Mean & Std. Deviation \\
\hline$\overline{\mathrm{DPR}}$ & 84 & .08309993537 & 1.3772285251 & .4075488068 & .23668979706 \\
\hline $\mathrm{CR}$ & 84 & .17838576681 & 12.724778978 & 2.7025584207 & 2.2304177855 \\
\hline DAR & 84 & .02544820285 & .67978374094 & .38388762598 & .15246313247 \\
\hline EPS & 84 & 11.53 & 2790.19 & 506.2293 & 651.64256 \\
\hline SIZE & 84 & 25.941652156 & 33.094967321 & 29.146332967 & 1.8040018689 \\
\hline $\begin{array}{l}\text { Valid } \\
\text { (listwise) }\end{array}$ & $\begin{array}{l}\mathrm{N} \\
\quad 84\end{array}$ & & & & \\
\hline
\end{tabular}

Sumber : SPSS 22, data diolah 2016

Variabel kebijakan dividen dari perusahaan yang dijadikan sampel memiliki rentang nilai dari 0,0831 sampai dengan 1,3772 . Perusahaan yang memiliki kebijakan dividen paling rendah yaitu PT Gajah Tunggal Tbk pada tahun 2012, sedangkan perusahaan yang memiliki kebijakan dividen paling tinggi yaitu PT Handjaya Mandala Sampoerna Tbk pada tahun 2013. Semakin mendekati atau melewati angka 1, maka kebijakan perusahaan untuk membayarkan dividen semakin tinggi. Nilai standar deviasi data kebijakan dividen sebesar 0,2367 lebih kecil dari nilai rata-rata sebesar 0,4075. Hal ini menunjukkan bahwa penyebaran data untuk variabel kebijakan dividen dalam penelitian ini merata dan tidak terdapat perbedaan yang terlalu tinggi antara satu data dengan data yang lainnya.

Variabel posisi likuiditas dari perusahaan yang dijadikan sampel memiliki rentang nilai dari 0,1784 sampai dengan 12,7248. Perusahaan dengan persentase posisi likuiditas paling rendah adalah PT Astra Otoparts Tbk pada tahun 2012, sedangkan perusahaan dengan persentase posisi likuiditas paling tinggi adalah PT Duta Pertiwi Nusantara Tbk pada tahun 2014. Semakin tinggi persentase posisi likuiditas, diharapkan perusahaan dapat membagikan dividen lebih besar. Nilai standar deviasi data posisi likuiditas sebesar 2,2304 lebih kecil dari nilai rata-rata sebesar 2,7025. Hal ini menunjukkan bahwa penyebaran data untuk variabel posisi likuiditas dalam penelitian ini merata dan tidak terdapat perbedaan yang tinggi antara data yang satu dengan data yang lainnya.

Variabel leverage dari perusahaan yang dijadikan sampel memiliki rentang nilai dari 0,0254 sampai dengan 0,6798. Perusahaan dengan persentase leverage paling rendah adalah PT KMI Wire And Cable Tbk pada tahun 2012, sedangkan perusahaan dengan persentase leverage paling tinggi adalah PT Unilever Indonesia Tbk pada tahun 2013. Semakin tinggi persentase leverage, dikhawatirkan perusahaan akan membagikan dividen lebih kecil. Nilai standar deviasi data leverage sebesar 0,1525 lebih kecil dari nilai rata-rata sebesar 0,3839. Hal ini menunjukkan bahwa penyebaran data untuk variabel leverage dalam penelitian ini merata dan tidak terdapat perbedaan yang tinggi antara data yang satu dengan data yang lainnya.

Variabel profitabilitas dari perusahaan yang dijadikan sampel memiliki rentang nilai dari 11,53 sampai dengan 2.790,19. Perusahaan dengan persentase profitabilitas paling rendah yaitu PT Sekar Laut Tbk pada tahun 2012, sedangkan perusahaan dengan persentase profitabilitas paling tinggi yaitu PT Gudang Garam Tbk pada tahun 2014. Semakin tinggi tingkat profitabilitas, diharapkan perusahaan dapat membagikan dividen lebih besar. Nilai standar deviasi data profitabilitas sebesar 651.6426 lebih 
besar dari rata-rata sebesar 506.229. Hal ini menunjukkan bahwa penyebaran data untuk variabel profitabilitas dalam penelitian ini tidak merata dan terdapat perbedaan yang tinggi antara data yang satu dengan data yang lainnya.

Variabel ukuran perusahaan dari perusahaan yang dijadikan sampel memiliki rentang nilai dari 25.9417 sampai dengan 33.0950. Perusahaan dengan persentase ukuran perusahaan paling rendah yaitu PT Duta Pertiwi Nusantara Tbk pada tahun 2012, sedangkan perusahaan dengan persentase ukuran perusahaan paling tinggi yaitu PT Astra International Tbk. pada tahun 2014. Semakin besar ukuran suatu perusahaan, diharapkan semakin besar pula dividen yang dibagikan. Nilai standar deviasi data ukuran perusahaan sebesar 1.8040 lebih kecil dari rata-rata sebesar 29.1463. Hal ini menunjukkan bahwa penyebaran data untuk variabel ukuran perusahaan dalam penelitian ini merata dan tidak terdapat perbedaan yang tinggi antara data yang satu dengan data yang lainnya.

Hasil Uji Asumsi Klasik

Hasil Uji Normalitas

Hasil Uji Normalitas dapat dilihat pada tabel 2

Tabel 2

Hasil Uji Normalitas Kolmogorov Smirnov (K-S)

One-Sample Kolmogorov-Smirnov Test

\begin{tabular}{|c|c|c|}
\hline & & $\begin{array}{l}\text { Unstandardized } \\
\text { Residual }\end{array}$ \\
\hline $\mathrm{N}$ & & 84 \\
\hline Normal Parameters ${ }^{\mathrm{a}, \mathrm{b}}$ & Mean & .0000000 \\
\hline & Std. Deviation & .47099627 \\
\hline Most Extreme Differences & Absolute & .094 \\
\hline & Positive & .073 \\
\hline & Negative & -.094 \\
\hline Test Statistic & & .094 \\
\hline Asymp. Sig. (2-tailed) & & $.062^{\mathrm{c}}$ \\
\hline a. Test distribution is Norm & & \\
\hline b. Calculated from data. & & \\
\hline c. Lilliefors Significance C & ection. & \\
\hline Sumber: SPSS 22, data sek & der diolah 2016 & \\
\hline
\end{tabular}

Berdasarkan tabel 2, diperoleh hasil bahwa tes statistik memiliki nilai sebesar 0,094 dengan signifikansi sebesar 0,062 . Hal ini menunjukkan bahwa nilai signifikansi lebih besar dari 0,05 (Asymp. Sig > 0,05), maka dapat dibuat kesimpulan bahwa data residual dalam penelitian ini berdistribusi normal.

\section{Hasil Uji Autokorelasi}

Hasil uji autokorelasi dapat dilihat pada tabel 3. 
Tabel 3

Hasil Uji Autokorelasi Runs Test

\begin{tabular}{lr}
\multicolumn{2}{c}{$\begin{array}{c}\text { Runs Test } \\
\text { Unstandardized Residual }\end{array}$} \\
\hline Test Value $^{\mathrm{a}}$ & .04805 \\
Cases $<$ Test Value & 42 \\
Cases >= Test Value & 42 \\
Total Cases & 84 \\
Number of Runs & 35 \\
Z & -1.756 \\
Asymp. Sig. (2-tailed) & .079 \\
a. Median & \\
Sumber: SPSS 22, data sekunder diolah 2016 &
\end{tabular}

Berdasarkan tabel 3, diperoleh hasil bahwa nilai test sebesar 0,04805 dengan signifikansi 0,079. Hal ini menunjukkan bahwa nilai signifikansi yang diperoleh lebih besar dari 0,05 (Asymp. Sig > 0,05), maka dapat disimpulkan bahwa data residual dalam penelitian ini tidak terjadi korelasi antar residual.

\section{Hasil Uji Multikolonieritas}

Hasil uji multikolonieritas dapat dilihat pada tabel 4.

\begin{tabular}{|c|c|c|c|}
\hline & Ha & $\begin{array}{c}\text { Tabel } 4 \\
\text { ji Multikoloni }\end{array}$ & \\
\hline & & $\begin{array}{l}\text { Coefficients }^{\mathrm{a}} \\
\text { Collineari }\end{array}$ & tistics \\
\hline & Model & Tolerance & VIF \\
\hline 1 & CR & .498 & 2.009 \\
\hline & DAR & .563 & 1.777 \\
\hline & EPS & .790 & 1.266 \\
\hline & SIZE & .697 & 1.434 \\
\hline
\end{tabular}

Berdasarkan tabel 4 , menunjukkan bahwa masing-masing variabel independen mempunyai nilai tolerance tidak kurang dari $0,1(>0,1)$ dan nilai variance inflation factor $(V I F)$ yang tidak lebih dari $10(<10)$. Dimana variabel posisi likuiditas $(\mathrm{CR})$, leverage (DAR), profitabilitas (EPS), dan ukuran perusahaan (SIZE) mempunyai nilai tolerance masing-masing sebesar 0,$498 ; 0,563 ; 0,790 ; 0,697$ serta memiliki nilai VIF masing-masing sebesar 2,$009 ; 1,777 ; 1,266 ; 1,434$.Dengan demikian, dapat dibuat kesimpulan bahwa model regresi yang digunakan untuk variabel-variabel independen dalam penelitian ini tidak terdapat masalah multikolonieritas.

\section{Hasil Uji Heterokedastisitas}

Hasil uji heterokedastisitas dapat dilihat pada gambar 1. 


\section{Gambar 1 \\ Hasil Uji Heteroskedastisitas Scatterplot}

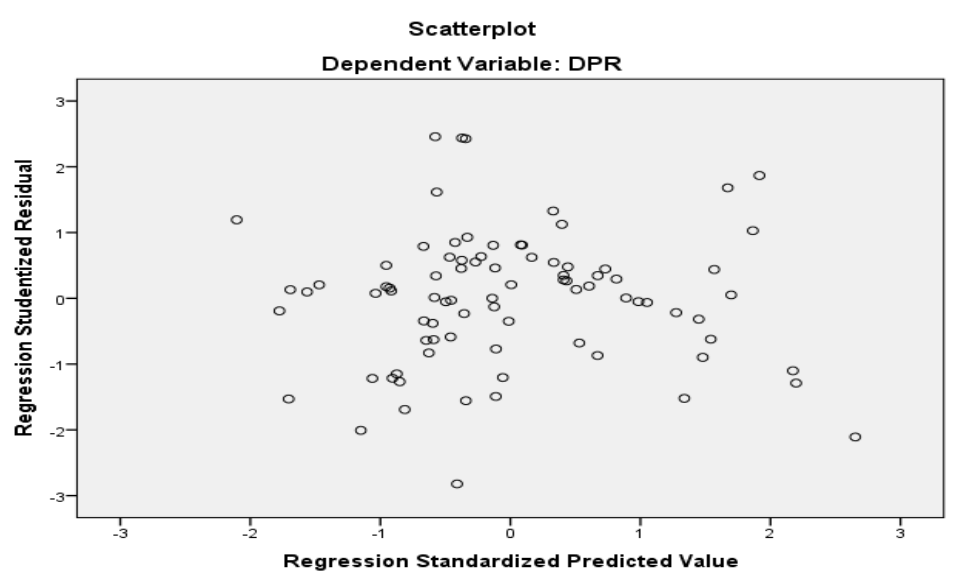

Sumber : SPSS 22, data diolah 2016

Berdasarkan gambar 1, grafik scatterplot menunjukkan bahwa titik-titik terlihat menyebar secara acak dan tersebar di atas maupun di bawah angka 0 pada sumbu Y. Hal ini dapatdisimpulkan bahwa model regresi tidak terjadi heteroskedastisitas, sehingga model regresi layak digunakan dalam penelitian ini.

\section{Hasil Uji Hipotesis}

Hasil Koefisien Determinasi $\left(\mathbf{R}^{2}\right)$

Hasil Koefisien Determinasi $\left(\mathrm{R}^{2}\right)$ dapat dilihat pada tabel 5.

Tabel 5

Hasil Koefisien Determinasi $\left(\mathbf{R}^{2}\right)$

Model Summary ${ }^{b}$

Adjusted R

\begin{tabular}{cccrr} 
Model & R & R Square & Square & \multicolumn{2}{c}{ Std. Error of the Estimate } \\
\hline 1 & $.500^{\mathrm{a}}$ & .250 & .212 & .482772990030994
\end{tabular}

a. Predictors: (Constant), SIZE, DAR, EPS, CR

b. Dependent Variable: DPR

Sumber : SPSS 22, data diolah 2016

Berdasarkan tabel 5, diperoleh hasil bahwa nilai adjusted $\mathrm{R}$ square sebesar 0,212 atau $21,1 \%$. Hal ini menunjukkan bahwa variasi variabel posisi likuiditas, leverage, profitabilitas, dan ukuran perusahaan hanya mampu menjelaskan sebesar $21,1 \%$ variasi variabel kebijakan dividen. Hal ini menunjukkan adanya variabel lain sebesar 78,9\% yang dapat menjelaskan variasi variabel kebijakan dividen yang tidak dimasukkan dalam model regresi penelitian ini seperti pertumbuhan perusahaan, free cash flow, risiko pasar, dan kesempatan investasi.

\section{Hasil Uji Signifikansi Simultan (Uji Statistik F)}

Hasil uji signifikansi simultan (uji statistik F) dapat dilihat pada tabel 6. 


\section{Tabel 6}

\section{Hasil Uji Statistik F}

\begin{tabular}{llrrrrr} 
& \multicolumn{2}{c}{ ANOVA $^{\mathbf{a}}$} & & \\
& Model & Sum of Squares & df & Mean Square & F & Sig. \\
\hline 1 & Regression & 6.134 & 4 & 1.534 & 6.580 & $.000^{\mathrm{b}}$ \\
& Residual & 18.413 & 79 & .233 & & \\
Total & 24.547 & 83 & & &
\end{tabular}

a. Dependent Variable: DPR

b. Predictors: (Constant), SIZE, DAR, EPS, CR

Sumber : SPSS 22, data sekunder diolah 2016

Berdasarkan tabel 6, nilai F diperoleh sebesar 6,580 dengan tingkat signifikansi 0,000 . Hal ini menunjukkan bahwa model regresi ini layak digunakan karena tingkat signifikansi lebih kecil dari 0,05, maka hipotesis diterima. Sehingga dapat dikatakan bahwa posisi likuiditas, leverage, profitabilitas, dan ukuran perusahaan secara bersama-sama (simultan) berpengaruh signifikan terhadap kebijakan dividen.

\section{Hasil Uji Signifikan Parameter Individual (Uji Statistik t)} tabel 7.

Hasil uji signifikansi parameter individual (uji statistik t) dapat dilihat pada

\begin{tabular}{|c|c|c|c|c|c|c|}
\hline & \multirow[b]{2}{*}{ Model } & \multicolumn{2}{|c|}{ Unstandardized Coefficients } & $\begin{array}{l}\text { Standardized } \\
\text { Coefficients }\end{array}$ & \multirow[b]{2}{*}{$\mathrm{t}$} & \multirow[b]{2}{*}{ Sig. } \\
\hline & & $\mathrm{B}$ & Std. Error & Beta & & \\
\hline \multirow[t]{5}{*}{1} & (Constant) & -3.092 & 1.071 & & -2.887 & .005 \\
\hline & CR & -.052 & .034 & -.213 & -1.542 & .127 \\
\hline & DAR & -1.116 & .463 & -.313 & -2.407 & .018 \\
\hline & EPS & .000 & .000 & .261 & 2.383 & .020 \\
\hline & SIZE & .086 & .035 & .285 & 2.446 & .017 \\
\hline
\end{tabular}

a. Dependent Variable: DPR

Sumber : SPSS 22, data diolah 2016

Berdasarkan tabel 7, maka dapat diketahui bahwa :

$\mathrm{DPR}=-3,092-0,052 \mathrm{CR}-1,116 \mathrm{DAR}+0,000218 \mathrm{EPS}+0,086 \mathrm{SIZE}$

1. Koefisien konstanta sebesar 3,092 dengan nilai negatif. Hal ini dapat diartikan bahwa kebijakan dividen akan bernilai -3,092 jika posisi likuiditas, leverage, profitabilitas, dan ukuran perusahaan masing-masing benilai 0 .

2. Variabel posisi likuiditas memiliki koefisien negatif sebesar 0,052 . Nilai koefisien regresi negatif menunjukkan bahwa setap kenaikan satu persen variabel posisi likuiditas, dengan asumsi bahwa variabel lain tetap maka akan menurunkan kebijakan dividen sebesar 0,052. Hasil uji variabel posisi likuiditas memiliki tingkat signifikansi 0,127 , yang berarti dapat dikatakan bahwa posisi likuiditas tidak berpengaruh terhadap kebijakan dividen, maka dapat disimpulkan bahwa hipotesis ditolak. 
3. Variabel leverage memiliki koefisien negatif sebesar 1,116. Nilai koefisien regresi negative menunjukan bahwa setiap kenaikkan satu persen variabel leverage, dengan asumsi bahwa variabel lain tetap maka akan menurunkan kebijakan dividen sebesar 1,116. Hasil uji variabel leverage memiliki tingkat signifikansi sebesar 0,018 yang berarti dapat dikatakan bahwa leverage berpengaruh negative terhadap kebijakan dividen, maka dapat disimpulkan bahwa hipotesis diterima.

4. Variabel profitabilitas memiliki koefisien positif sebesar 0,000218. Nilai koefisien regresi positif menunjukkan bahwa setiap kenaikkan satu persen variabel profitabilitas, dengan asumsi bahwa variabel lain tetap maka akan meningkatkan kebijakan dividen sebesar 0,000218. Hasil uji variabel profitabilitas memiliki tingkat signifikansi sebesar 0,020 , yang berarti dapat dikatakan bahwa profitabilitas berpengaruh positif terhadap kebijakan dividen, maka dapat disimpulkan bahwa hipotesi sditerima.

5. Variabel ukuran perusahaan memiliki koefisien positif sebesar 0,086. Nilai koefisien positif menunjukkan bahwa setiap kenaikkan satu persen variabel ukuran perusahaan, dengan asumsi bahwa variabel lain tetap maka akan meningkatkan kebijakan dividen sebesar 0,086. Hasil uji variabel ukuran perusahaan memiliki tingkat signifikansi sebesar 0,017, yang berarti dapat dikatakan bahwa ukuran perusahaan berpengaruh positif terhadap kebijakan dividen, maka dapat disimpulkan bahwa hipotesis diterima.

\section{SIMPULAN, SARAN, DAN KETERBATASAN PENELITIAN}

\subsection{Simpulan}

Penelitian ini bertujuan untuk mengetahui pengaruh posisi likuiditas, leverage, profitabilitas, dan ukuran perusahaanterhadap kebijakan dividen. Sampel dalam penelitian ini adalah 28 perusahaan manufaktur yang terdaftar di Bursa Efek Indonesia selama periode 2012, 2013 dan 2014. Berdasarkan data yang telah dikumpulkan dan diolah sehingga memperoleh hasil pengujian yang dilakukan permasalahan dengan menggunakan model regresi linier berganda, maka dapat di simpulkan sebagai berikut

1. Posisi likuiditas tidak berpengaruh terhadap kebijakan dividen. Hal ini menunjukkan bahwa besar kecilnya posisi likuiditas tidak mempunyai pengaruh terhadap pembayaran dividen dikarenakan beberapa perusahaan menggunakan kebijakan dividen yang stabil, selain itu pembayaran dividen tidak hanya menggunakan kas dan asset lancar, tetapi dapat menggunakan properti dan saham.

2. Leverage berpengaruh negative terhadap kebijakan dividen. Hal ini menunjukkan bahwa semakin besar proporsi utang, maka akan semakin kecil kemampuan perusahaan untuk membayar dividen.

3. Profitabilitas berpengaruh positif terhadap kebijakan dividen. Hal ini menunjukkan bahwa semakin besar profit yang dihasilkan perusahaan, maka semakin besar pula dividen yang akan dibayaroleh perusahaan.

4. Ukuran perusahaan berpengaruh positif terhadap kebijakan dividen. Hal ini menunjukkan bahwa semakin besar ukuran suatu perusahaan, maka semakin besar pula dividen yang akan dibayar oleh perusahaan. 
5. Berdasarkan hasil penelitian dari uji simultan (Uji F) menunjukkan bahwa variabel posisi likuiditas, leverage, profitabilitas, dan ukuran perusahaan secara simultan berpengaruh terhadap kebijakan dividen.

\subsection{Saran}

Berdasarkan hasil penelitian dan simpulan, maka peneliti dapat memberikan saran sebagai berikut :

1. Perusahaan disarankan untuk lebih memperhatikan rasio likuiditasnya. Karena asset lancar yang tinggi belum tentu disebabkan kas yang tinggi, tetapi disebabkan oleh nilai piutang dan persediaan yang tinggi. Sementara piutang dan persediaan dianggap memiliki waktu relative lama untuk diuangkan, apabila perusahaan membutuhkan dana cepat untuk membayar kewajiban jangka pendeknya. Bila perusahaan memiliki kas yang lebih besar dibanding aktiva lancar lainnya, maka perusahaan dapat segera melunasi kewajibannya dan dapat menambah pembayaran dividen.

2. Dalam hal meningkatkan nilai kas, perusahaan diharapkan dapat meningkatkan penjualan tunainya dengan cara meningkatkan kualitas produk, diversifikasi produk, promosi ke tingkat yang lebih luas, dan ekspansi usaha. Terutama untuk sektor rokok dan sektor makanan dan minuman yang lebih dibutuhkan oleh masyarakat.

3. Bagi investor yang ingin menanamkan modalnya disebuah perusahaan dan ingin mendapatkan dividen yang besar harus memperhatikan dan mempertimbangkan ukuran perusahaan tersebut. Karena dalam penelitian ini, ukuran perusahaan memiliki pengaruh paling besar dalam kebijakan dividen. Menurut Handayani dan Hadinugroho (2009), perusahaan yang memiliki ukuran besar akan lebih mudah memasuki pasar modal sehingga dengan kesempatan ini, perusahaan akan membayar dividen besar kepada pemegang saham.

\subsection{Keterbatasan Penelitian dan Pengembangan Penelitian Selanjutnya}

Peneliti menyadari bahwa hasil dari penelitian ini masih jauh dari kesempurnaan. Hal ini disebabkan masih adanya keterbasan dalam penelitian ini sebagai berikut :

1. Penelitian ini hanya menggunakan perusahaan manufaktur yang terdaftar di Bursa Efek Indonesia sebagai objek penelitian, sehingga penelitian ini tidak dapat menjelaskan kebijakan dividen pada setiap jenis perusahaan yang beroperasi di Indonesia. Penelitian selanjutnya dapat menggunakan objek penelitian lainnya seperti perusahaan pertambangan, real estate dan property, jasa keuangan dan sebagainya.

2. Penelitian ini hanya menggunakan periode penelitian selama tiga tahun yaitu 2012, 2013, 2014 dan hanya mendapatkan sampel sebanyak 28 untuk setiap periode. Penelitian selanjutnya dapat menambahkan periode penelitian sehingga memiliki observasi yang semakin banyak.

3. Penelitian ini hanya menggunakan posisi likuiditas, leverage, profitabilitas, dan ukuran perusahaan sebagai variabel dependen atau bebas. Sementara ada beberapa variabel lain yang di duga berbengaruh 
terhadap kebijakan dividen, misalnya pertumbuhan perusahaan, kesempatan investasi, free cash flow, dan risiko pasar.

4. Dalam penelitian ini variabel posisi likuiditas hanya diukur menggunakan current ratio, variabel leverage hanya diukur dengan debt to assets ratio, dan variabel profitabilitas yang hanya diukur dengan earnings per share. Sementara masih banyak cara untuk mengukur variabel posisi likuiditas, leverage, dan profitabilitas.

\section{DAFTAR PUSTAKA}

Arikunto, Suharsimi. 2013. Prosedur Penelitian: Suatu Pendekatan Praktik. Jakarta: Rineka Cipta

Brigham, Eugene F. dan Joel F. Houston. (2009). Dasar-dasar Manajemen Keuangan, Edisi Kesepuluh. (Ali Akbar Yulianto, Penerjemah). Jakarta: Salemba Empat

Fahmi, Irham. 2012. Pengantar Pasar Modal. Bandung: Alfabeta.

Ghozali, Imam. 2013. Aplikasi Analisis Multivariate Dengan Program IBM SPSS 21 Update PLS Regresi Edisi. Semarang: Universitas Diponegoro.

Kasmir. 2015. Analisis Laporan Keuangan. Jakarta: Rajawali Pers

Lopolusi, Ita. 2013. Analisis Faktor-Faktor yang Mempengaruhi Kebijakan Dividen Sektor Manufaktur yang Terdaftar di PT Bursa Efek Indonesia Periode 20072011. Jurnal Ilmiah Universitas Surabaya, 2(1).

Nurkholis. 2015. Analisis Faktor-faktor yng mempengruhi Kebijakan Dividen (Studi Empiris pada Perusahaan Manufaktur yang terdaftar di BEI periode 20102013). Skripsi. Fakultas Ekonomika dan Bisnis Universitas Diponegoro. Semarang.

Nursandari, Meilina. 2014. Analisis Faktor yang mempengaruhi Kebijakan Dividen dengan Size (Ukuran Perusahaan) sebagai variabel moderasi pada Perusahaan Manufaktur yang terdaftar di Bursa Efek Indonesia. Skripsi. Fakultas Ekonomi, Universitas Negeri Yogyakarta.

Palino, Novianty. 2012. Faktor-faktor yang mempengaruhi Dividen Tunai pada Perusahaan Manufaktur yang terdaftar di BEI. Skripsi. Fakultas Ekonomi dan Bisnis, Universitas Hasanuddin, Makassar.

Pasadena, Rizka Persia. 2013. Pengaruh Likuiditas, Leverage, Profitabilitas, dan Ukuran Perusahaan terhadap Kebijakan Dividen pada Perusahaan Manufaktur yang terdaftar di Bursa Efek Indonesia. Skripsi. Fakultas Ekonomi dan Bisnis, Universitas Islam Negeri Syarif Hidayatullah, Jakarta.

Puspita, Fira. 2009. Analisa Faktor - faktor yang Mempengaruhi KebijakanDividend Payout Ratio(Studi Kasus Pada Perusahaan Yang Terdaftar Di Bursa Efek Indonesia Periode 2005-2007). Tesis.Universitas Diponegoro, Semarang. 
Puspitasari, Novia Ayu. 2014. Faktor-faktor yang berpengaruh terhadap Kebijakan Dividen. Skripsi. Fakultas Ekonomika dan Bisnis, Universitas Diponegoro, Semarang.

Subramanyam, K.R dan J.J. Wild. 2013. Analisis Laporan Keuangan Edisi 10 Buku 2. (Dewi Yanti, Penerjemah). Jakarta: Salemba Empat.

Subramanyam, K.R dan J.J. Wild. 2014. Analisis Laporan Keuangan Edisi 10 Buku 1. (Dewi Yanti, Penerjemah). Jakarta: Salemba Empat.

Taufani, Hendyawan Ahmad. 2014. Analisis Faktor-faktor yang mempengaruhi Kebijakan Dividen pada Perusahaan Consumer Goods Industry yang terdaftar di Bursa Efek Indonesia tahun 2009-2012. Skripsi. Fakultas Ekonomi dan Bisnis, Universitas Pembangunan Nasional "Veteran”, Jawa Timur

Weston, J, Fred dan Eugene F. Brigham. 1994. Dasar-dasar Manajemen Keuangan, Jilid 1 (Alfonsus Sirait, Penerjemah). Jakarta: Erlangga.

http://www.idx.co.id/Home/NewsAndAnnouncement/News/ReadNews/tabid/192/item ID/d260e3fb-4c95-43a6-938a-81148442187f/language/id-ID/Default-aspx (diakses 1 Januari 2016).

http://www.idx.co.id/id-id/beranda/publikasi/lq45.aspx (diakses 22 Desember 2015). 